\title{
MEMBANGUN KARAKTER MULIA PADA ANAK PERSPEKTIF KEWIRAUSAHAAN
}

\author{
Ita Nurcholifah \\ Fakultas Syari'ah dan Ekonomi Islam (FSEI) \\ Institut Agama Islam Negeri (IAIN) Pontianak \\ E-mail : inurcholifah@yahoo.co.id
}

\begin{abstract}
The advanced growth especially on economic sector is an important matter in Indonesia nowadays. The effective booster to develop the nation's economic is to expand the job emplyment that the societies have a powverful purchasing. Furthermore, the potential matter to create more chances for people to work is to duplicate more entrepreneurs in this country. Besides, it should start from an early age by building entrepreneurial character in children. To develop the entrepreneurial character there are several ways could be taken: First, build the self-confidence of children. Second, emphasize the hard-work desire or the willingness to be more active. Third, evolve their self-esteem that they are able to take a control of their own life. Forth, develop the conviction behavior or Istiqomah. Fifth, keep the precision or accuracy. Sixth, build the creative mindset. Seventh, help the children to solve their problems. And the last but not least, acquire the objective attitude of seeing or judging anything. Moreover, building the entrepreneurial character in children by giving them a good education, whether at home or family environment, social environment or community and school, should firstly promote the process of developing the entrepreneurial character itself. Likewise, to develop the entrepreneurial character should be done in precise and accurate ways so that the efforts to build the entrepreneurial character in children are not futile. Meanwhile, an attempt is made by describing it repeatedly and continuously, but it also needs the participation of parents at home, community leaders in the society, and also a teacher at school, in order to position themselves as educators who tend to give guidance and direction positively, rather than coercing the will of the children, especially in entrepreneurial character pinned on them. To conclude, by prioritizing the sincerity and gentleness learning ways, will certainly affect the children strongly.
\end{abstract}

Keywords: Character, Entrepreneur

\section{PENDAHULUAN}

Usaha mendorong percepatan kemajuan khususnya di sektor ekonomi merupakan suatu hal yang sangat penting di Indonesia saat ini. Hal itu dikarenakan saat ini terjadi perlambatan sektor ekonomi yang kemudian membuat ekonomi bangsa menjadi stagnan dan berdampak pada menurunnya nilai tukar rupiah terhadap beberapa mata uang asing terutama Dollar Amerika yang banyak dijadikan standar pembayaran dalam sistem perdagangan global.

Meskipun saat ini ekonomi bangsa kita sedang mengalami perlambatan, tapi tidaklah terlalu parah seperti kejadiaan resesi ekonomi yang melanda bangsa ini pada tahun 1998. Namun bila kejadian ini terus berlanjut tanpa adanya daya dorong yang kuat terhadap percepatan laju perekonomian bangsa ini bukan mustahil juga kejadian resesi ekonomi bangsa kita ini akan mengikuti kondisi kolaps seperti kejadian di tahun 1998 atau mungkin lebih parah lagi.

Daya dorong yang paling strategis guna memajukan ekonomi bangsa saat ini agar tidak mengalami kebangkrutan ekonomi adalah dengan cara memperluas lapangan pekerjaan sehingga daya beli masyarakat menjadi kuat dan sektor perdagangan maupun perindustrian kembali bergairah serta dapat menyumbangkan devisa bagi negara.

Penciptaan lapangan kerja tentu bukan suatu hal yang gampang namun juga bukan merupakan suatu hal yang sangat sulit untuk dilakukan. Penciptaan lapangan kerja saat ini yang paling 
gampang dilakukan adalah dengan mempercepat prakasa pemerintah untuk segera membelanjakan dana yang ada padanya ke sektor pembangunan padat karya sehingga dapat melibatkan sebanyak mungkin tenaga kerja dalam waktu singkat. Tapi pola seperti itu mungkin akan efektif guna mengganjal stagnasi ekonomi bangsa namun tidak akan dapat bertahan dalam waktu yang panjang karena tidak permanen sifatnya, selain itu juga tidak dapat menjangkau semua sektor untuk ikut bergerak secara maksimal.

Pola penciptaan lapangan kerja yang paling efektif guna memperbanyak lapangan kerja tentunya dengan memperbanyak wirausahawan di negeri ini. Semakin banyak wirausahawan yang tumbuh dan berkembang di seluruh pelosok negeri ini tentu akan secara alami memperbanyak jumlah lapangan kerja bagi masyarakat Indonesia yang masih menganggur yang sangat mendambakan pekerjaan guna mendapatkan penghasilan untuk mempertahankan hidup mereka dan juga keluarga mereka.

Banyaknya wirausahawan yang dapat diciptakan bukan hanya dapat memperbanyak jumlah tenaga kerja yang terserap secara kuantitas tapi juga secara kualitas dapat menjaga meningkatkan kemampuan dan daya saing bangsa terhadap gempuran ekonomi bangsa lain di seluruh muka bumi ini. Sehingga dapat dikatakan bahwa untuk memperbaiki nasib bangsa Indoesia ini ke depan tentu sedini mungkin kita harus dapat menciptakan sebanyak mugkin wirausahawan, dan hal itu harus dimulai dari usia dini dengan cara membangun karakter kewirausahaan pada anak. Harapan yang dinanti tentunya kelak dewasa, anak-anak tersebut akan menjadi wirausahawan handal yang dapat bersaing dalam segala sektor perekonomian yang tentunya akan bermuara pada kemajuan dan kejayaan bangsa Indonesia.

\section{KARAKTER}

Sebelum mengupas tuntas tentang membangun karakter mulia pada anak perspektif kewirausahaan, tentu langkah awal yang perlu di gali dan ddicermati adalah persoalan karakter itu sendiri.Karakter merupakan suatu hal yang sangat penting dalam hidup ini.Menurut Sumahamijaya dkk (2003: 33), Yang perlu sekali bagi pemuda kita ialah karakter. Rakyat Indonesia, yang mencitacitakan derajat yang sama dengan bangsa lain di dunia ini, lebih butuh pemimpin yang mempunyai karakter. Sebab itu mendidik karakter itulah yang patut diusahakan benar. Bukan kepintaran yang diutamakan disini, melainkan karakter, watak teguh yang disertai oleh kemauan.

Begitu pentingnya karakter, lalu apa sebenarnya karakter itu?, mengacu kepada Oxford AdvancedLearner's Dictionary Of Current English, Oxford University Press. London, 1981, Oleh AS. Hornby, kata character terdiri dari dua pengertian, antara lain :Pertama, (of a person, community, race, atc) mental or moral nature; mental or moral qualities that make one person, race, etc different from others. Diterjemahkan kedalam bahasa Indonesia adalah keadaan moral atau mental seseorang, masyarakat, bangsa dan sebagainya; kualitas mental atau moral yang membentuk seseorang, bangsa dan sebagainya, berbeda dari yang lain. Kedua, Moral Strength (kekuatan akhlak atau daya bathin). Di dalam kamus ini pun tertulis contoh sebuah kalimat: Should character building be the chief aim of education? (adalah pembentukan atau pembangunan akhlak menjadi tujuan utama pendidikan ?) Sumahamijaya dll (2003: 30).

Hermawan Kertajaya, dalam Asmani (2011: 28), mengemukakan bahwa karakter adalah cirri khas yang dimiliki oleh suatu benda atau individu. Cirri khas tersebut adalah asli dan mengakar pada kepribadian benda atau individu tersebut, dan merupakan mesin yang mendorong bagaimana sesorang bertindak, bersikap, berujar, dan merespons sesuatu. 
Sedangkan menurut Doni Koesoema Albertus, dalam Asmani (2011: 28), karakter diasosiasikan dengan temperamen yang memberikan sebuah definisi yang menekankan unsur psikososial yang dikaitkan dengan pendidikan dan konteks lingkungan. Karakter juga dipahami dari sudut pandang behavioral yang menekankan unsur somato-psikis yang dimiliki oleh individu sejak lahir. Di sini, karakter dianggap sama dengan kepribadian. Kepribadian dianggap sebagai cirri atau karakteristik atau gaya atau sifat khas dari diri seseorang, yang bersumber dari bentukan-bentukan yang diterima dari lingkungan, misalnya pengaruh keluarga pada masa kecil dan bawaan seseorang sejak lahir.

Beberapa pendapat di atas yang coba mengungkapkan secara rinci tentang istilah karakter menunjukkan bahwa sebenarnya karakter adalah suatu sikap mental sesorang yang melatarbelakangi segala sikap dan tindakannya dalam segenap derap langkahnya dalam menjalankan segala aktivitas di dalam kehidupannya.

Sikap mental yang mampu melatarbelakangi segala tindakan seseorang tentu merupakan suatu hal yang sangat penting bagi setiap orang dan hal tersebut juga pernah dilakukan suatu penelitian. Menurut Gede Raka dkk dalam Asmani (2011: 20), sebuah studi yang dilakukan terhadap 449 orang menejer, atau setingkat menejer di Indonesia menunjukkan bahwa faktor karakter mempunyai kontribusi yang paling besar terhadap persepsi berhasil atau tidaknya seseorang dalam kehidupan. Dalam semua keadaan, sebuah kreatifitas, kepercayaan diri, dan mentalitas yang tinggi sangat kontributif terhadap keberhasilan yang dirasakan oleh responden. Kontribusi integritas dan idealism sangat penting dalam lingkungan yang bergejolak dan penuh ketidakpastian.

Pada studi yang lain, yang dilakukan oleh Martin E.P. Saligman dalam Asmani (2011: 2021), menunjukkan hasil eksperimen mengenai pengaruh optimisme terhadap keberhasilan seseorang dalam pekerjaan. Eksperimen tersebut bahkan membuktikan bahwa orang-orang yang optimis, namun pada tahap seleksi tidak memenuhi persyaratan lulus dari segi profil kompetensi untuk pekerjaannya (kareer profile), kinerjanya lebih tinggi dibandingkan dengan mereka yang memiliki kompetensi tinggi namun tidak optimis. Sifat optimis merupakan bagian dari karakter seseorang.

Pentingnya sebuah karakter yang melekat kuat pada seseorang terlebih bila disematkan pada anak-anak sedini mungkin tentu akan lebih bermanfaat dan berguna bagi pembentukan karakter yang mulia bagi seseorang di dalam mengembangkan dan memajukan diri, lingkungan maupun bangsa dan negara dimanapun orang itu berada. Oleh karena itu, pembangunan karakter yang dilakukan sedini mungkin tentu akan sangat berguna dalam menyematkan berbagai karakter yang mulia pada anakanak.

\section{KARAKTER MULIA PADA ANAK}

Pentingnya suatu karakter bagi setiap individu terutama anak-anak tentu menuntut orangtua, guru maupun lingkungan sekitar untuk dapat menyematkan suatu karakter yang mulia pada anak. Dan karakter tersebut haruslah dapat menjawab berbagai problema kekinian pada lingkungan masyarakat maupun Negara Republik Indonesia ini.

Berkenaan dengan karakter mulia pada anak, menurut Asmani (2011: 36-41), berdasarkan kajian berbagai nilai agama, norma sosial, peraturan atau hukum, etika akademik, dan prinsip-prinsip HAM, telah teridentifikasi butir-butir nilai-nilai yang dikelompokkan menjadi lima nilai utama, yaitu nilai-nilai perilaku manusia yang berhubungan dengan Tuhan Yang Maha Esa, diri sendiri, sesama manusia, lingkungan, dan kebangsaan. Berikut adalah daftar dan deskripsi ringkas nilai-nilai utama yang dimaksud.Pertama, Nilai karakter dalam hubungannya dengan Tuhan. Nilai ini bersifat religious. 
Dengan kata lain, pikiran, perkataan, dan tindakan seseorang diupayakan selalu berdasarkan pada nilainilai ketuhanan dan/atau ajaran agama.

Kedua, Nilai karakter hubungannya dengan diri sendiri.Ada beberapa karakter yang berhubungan dengan diri sendiri, berikut beberapa nilai tersebut.a). Jujur. Jujur atau kejujuran merupakan perilaku yang didasarkan pada upaya menjadikan diri sebagai orang yang selalu dapat dipercaya. Hal ini diwujudkan dalam hal perkataan, tindakan, dan pekerjaan, baik terhadap diri sendiri maupun pihak lain. Kejujuran merupakan perilaku yang didasarkan pada upaya menjadikan diri sebagai orang yang selalu dapat dipercaya, baik terhadap diri sendiri maupun pihak lain. b). Bertanggung Jawab. Ini merupakan sikap dan perilaku seseorang untuk melaksanakan tugas dan kewajibannya, sebagaimana yang seharusnya ia lakukan terhadap diri sendiri, masyarakat, lingkungan (alam, dan budaya), Negara dan Tuhan Yang Maha Esa. c). Bergaya Hidup Sehat. Segala upaya untuk menerapkan kebiasaan yang baik dalam menciptakan hidup yang sehat dan menghindarkan kebiasaan buruk yang dapat mengganggu kesehatan. d). Disiplin. Tindakan yang menunjukkan perilaku tertib dan patuh pada berbagai ketentuan dan peraturan. e). Kerja Keras. Perilaku yang menunjukkan upaya sungguhsungguh dalam berbagai hambatan guna menyelesaikan tugas (belajar/pekerjaan) dengan sebaikbaiknya. f). Percaya Diri. Sikap yakin akan kemampuan diri sendiri terhadap pemenuhan tercapainya setiap keinginan dan harapannya. g). Berjiwa Wirausaha. Sikap dan perilaku yang mandiri dan pandai atau berbakat mengenali produk baru, menentukan cara produksi baru, menyusun operasi untuk pengadaan produk baru, memasarkannya, serta mengatur permodalan operasinya. h). Berpikir Logis, Kritis, Kreatif, dan Inovatif. Berpikir dan melakukan sesuatu secara nyata atau logika untuk menghasilkan cara atau hasil baru dan mutakhir dari sesuatu yang telah dimiliki. i). Mandiri. Sikap dan perilaku yang tidak mudah bergantung pada orang lain dalam menyelesaikan tugas-tugas. j). Ingin Tahu. Sikap dan tindakan yang selalu berupaya untuk mengetahui lebih mendalam dan meluas dari sesuatu yang dipelajari, dilihat, dan didengar. k). Cinta Ilmu. Cara berpikir, dan berbuat yang menunjukkan kesetiaan, kepedulian, dan penghatgaan yang tinggi terhadap pengetahuan.

Ketiga, Nilai karakter hubungannya dengan sesama.a). Sadar hak dan kewajiaban diri dan orang lain. Sikap tahu dan mengerti serta melasanakan sesuatu yang menjadi milik atau hak diri sendiri dan orang lain, serta tugas atau kewajiban diri sendiri dan orang lain. b).Patuh pada aturan-aturan sosial. Sikap menurut dan taat terhadap aturan-aturan berkenaan dengan masyarakat dan kepentingan umum. c). Menghargai karya dan prestasi orang lain. Menghargai karya dan prestasi orang lain merupakan sikap dan tindakan yang mendorong diri untuk menghasilkan sesuatu yang berguna bagi masyarakat. Serta, mengakui dan menghormati keberhasilan orang lain. d). Santun. Santun merupakan sifat yang halus dan baik dari sudut pandang tata bahasa maupun tata perilakunya kepada semua orang. e). Demokratis. Cara berpikir, bersikap, dan bertindak yang menilai sama hak dan kewajiban diri sendiri dan orang lain.

Keempat, Nilai karakter hubungannya dengan lingkungan. Hal ini berkenaan dengan kepedulian terhadap sosial dan lingkungan. Nilai karakter tersebut berupa sikap dan tindakan yang selalu berupaya mencegah kerusakan pada lingkungan alam disekitarnya. Selain itu, mengembangkan upaya-upaya untuk memperbaiki kerusakan alam yang sudah terjadi dan selalu ingin member bantuan bagi orang lain dan masyarakat yang membutuhkan.

Kelima, Nilai kebangsaan. Artinya, cara berpikir, bertindak, dan wawasan yang menempatkan kepentingan bangsa dan negara di atas kepentingan diri dan kelompok. a). Nasionalis. Cara berpikir, sikap, dan berbuat yang menunjukkan kesetiaan, kepedulian, dan penghargaan yang tinggi terhadap bahasa, lingkungan fisik, sosial, budaya, ekonomi, dan politik bangsa. b). Menghargai keberagaman. 
Sikap memberikan respek atau hormat terhadap berbagai macam hal, baik berbentuk fisik, sifat, adat, budaya, suku, maupun agama.

Khususnya pada nilai-nilai karakter dalam hubungannya dengan diri sendiri, yang menempatkan nilai karakter berjiwa wirausaha sebagai salah satu poin dari beberapa poin yang di kemukakan di atas, tentu sangat realistis bila dikembangkan sebagai karakter mulia yang benar-benar disematkan bagi anak-anak generasi penerus bangsa ini, mengingat bangsa ini sangat membutuhkan figure-figur yang benar-benar memiliki karakter berjiwa wirausaha guna membawa bangsa ini ke kancah persaingan bebas yang sangat membutuhan perjuangan para entrepreneur yang sanggup memajukan perekonomian bangsa yang sedang sekarat ini.

Karakter berjiwa wirausaha sebagimana disebutkan di atas, menunjukkan bahwa sifat dan sikap mental seseorang atau anak di dalam upaya mengembangkan segenap potensi ekonominya merupakan sebuah karakter yang mulia yang patut dipelihara dan ditumbuh kembangkan guna membantu diri mereka sendiri maupun orang lain dalam mengatasi berbagai problem kehidupan khususnya yang berkenaan dengan sektor ekonomi, seperti halnya dengan kondisi ekonomi bangsa kita saat ini yang sedang terjadi pelemahan ekonomi.

Sikap dan perilaku mandiri sebagai pondasi karakter jiwa berwirausaha sebagaimana disebutkan di atas, juga sesuai dengan pendapat Sumahamijaya dll (2003: 31) menurutnya, karakter mandiri ini memacu dan mendorong seseorang untuk memecahkan sendiri persoalan hidup dan kehidupannya, sehingga dia termotivasi untuk berinisiatif, berkreasi, berinovasi, produktif, dan bekerja keras.

\section{KEWIRAUSAHAAN}

Di dunia ini semua manusia menginginkan dalam menjalani hidup dan kehidupan yang menyenangkan dan bahagia. Kehidupan itu berarti jauh dari kesulitan yang tidak menyenangkan. Manusia selalu berusaha mencari kemudahan-kemudahan, meskipun tidak ada manusia yang menyenangi hidup tanpa sesuatu atau guna mengisi kekosongan maupun menyelesaikan masalahmasalah yang kecil atau besar yang sulit dan pelik. Manusia juga tidak menyenangi jika dalam kehidupan ini harus diam dan tidak berbuat sesuatu, selain tidur jika mengantuk, duduk-duduk dan makan apabila dalam keadaan jaga/tidak tidur (Nawawi, 1994 :69).

Guna menggapai kebahagian hidup tentunya manusia harus berusaha atau berwirausaha sehingga dari kegiatan berwirausaha tersebut manusia mendapatkan hasil atau keuntungan yang kemudian dapat dipakai untuk membahagiakan diri manusia tersebut. Hal itu sesuai dengan pendapat Valentino Dinsi dkk (2004: 14) bahwa "totalitas kehidupan manusia, menuntut jiwa kewirausahaan agar seseorang berhasil dalam hidupnya". Kewirausahaan merupakan opsi karir yang menarik orang yang ingin meningkatkan kualitas hidupnya (Boone \& Kurtz 2002:221).

Berkaitan dengan hal tersebut, menurut Hendro (2011: 9), dari survey tentang sumber kekayaan orang-orang kaya di dunia, dapat disimpulkan kekayaan itu diperoleh karena mayoritas ( \pm 80\%) menjadi pengusaha (wirausahawan atau entrepreneur).

Begitu pentingnya kewirausahaan sebagaimana beberapa pendapat di atas, lalu apa sebenarnya kewirausahaan itu ?, mengacu kepada Kamus Besar Bahasa Indonesia, edisi keduaDepdikbud, Balai Pustaka, 1996 halaman 11-30 dalam bukunya Suparman Sumahamijaya (2003:67) pengertian kata wirausaha berasal dari kata wiraswasta. Wirausaha itu sendiri adalah wiraswasta. Masyarakat bebas memakai istilah yang mana saja. Yang lebih penting bukanlah memperdebatkan soal istilah, namun penerapannyalah yang harus diutamakan. Sedangkan menurut Benedicta (2003:21) kata 
"Wirausaha" merupakan gabungan kata wira (=gagah berani, perkasa) dan usaha. Jadi wirausaha berarti orang yang gagah berani atau perkasa dalam usaha.

Adapun secara etimologi menurut Rusdiana (2014: 45), bahwa istilah kewirausahaan berasal dari kata wira dan usaha.Wira berarti pejuang, pahlawan, manusia unggul, teladan, berbudi luhur, gagah berani, dan berwatak agung. Adapun usaha berarti perbuatan amal, bekerja, berbuat sesuatu.Dengan demikian wirausaha adalah pejuang atau pahlawan yang berbuat sesuatu.

Pendapat lain tentang pengertian Wirausahawan di kemukan oleh Kasmir. Menurut Kasmir (2007:18) Secara sederhana arti wirausahawan (entrepreneur) adalah orang yang berjiwa berani mengambil resiko untuk membuka usaha dalam berbagai kesempatan Berjiwa berani mengambil resiko artinya bermental mandiri dan berani memulai usaha, tanpa diliputi rasa takut atau cemas sekalipun dalam kondisi tidak pasti.

Sedangkan menurut Mas'ud Machfoedz dkk (2008:9), seorang wirausahawan adalah pribadi yang mandiri dalam mengejar prestasi, ia berani mengambil resiko untuk mulai mengelola bisnis demi mendapatkan laba. Tidak jauh berbeda dengan pendapat tersebut, menurut Buchari Alma (2003:21) Seorang wirausaha adalah orang yang melihat adanya peluang kemudian menciptakan sebuah organisasi untuk memanfaatkan peluang tersebut.

Bebearapa pendapat di atas dengan gamblang merumuskan pengertian dari wirausaha dan wirausahawan, lalu apa sebetulnya pengertian dari istilah kewirausahaan. Menurut Rusdiana (2014: 46), wirausaha mengarah kepada orang yang melakukan usaha/kegiatan dengan segala kemampuan yang dimilikinya, sedangkan kewirausahaan (entrepreneurship) menunjuk pada sikap mental yang dimiliki seseorang wirausaha dalam melaksanakan usaha/kegiatan.

Menurut Hendro (2011: 30), bahwa Entrepreneurship adalah suatu kemampuan untuk mengelola sesuatu yang ada dalam diri anda untuk dimanfaatkan dan ditingkatkan agar lebih optimal (baik) sehingga bisa meningkatkan tarap hidup anda di masa mendatang.

Dari beberapa pengertian tersebut di atas maka dapat disimpulkan bahwa kewirausahaan (entrepreneur) adalah sikap mental seseorang yang mempunyai semangat untuk mandiri dalam memulai suatu usaha/bisnis, mampu menemukan peluang-peluang usaha dan berani menghadapi resiko dari setiap upaya yang dilakukannya.

Kegiatan Wirausaha dapat dikelola sendiri atau dikelola orang lain. Dikelola sendiri artinya si pengusaha memiliki modal uang dan kemampuan langsung terjun mengelola usahanya. Sementara itu jika dikelola orang lain, adalah si pengusaha cukup menyetor sejumlah uang dan pengelolaan usahanya diserahkan kepada pihak lain. Itu berarti dalam wirausaha seseorang dapat menyetor sejumlah uang kemudian dikelola orang lain atau seseorang menjadi donatur sekaligus pengelolanya, atau dapat pula dana yang disetor menjadi bukti kepemilikannya dalam bentuk tenaga yang dikonversikan ke dalam bentuk saham dengan jumlah tertentu.

Jadi, untuk berwirausaha dapat dilakukan dengan cara: Pertama, memiliki modal sekaligus menjadi pengelola. Ini berarti si pengusaha mengeluarkan modal sendiri untuk memulai dan menjalankan aktivitas usahanya. Pengelolaannya pun dilakukan oleh pengusaha itu sendiri. Pengusaha seperti ini merupakan pemilik modal tunggal sekaligus pengelola atau manajemennya dipegang seorang diri. Kedua, menyetor modal dan pengelolaan ditangani oleh pihak mitra. Ini berarti si pengusaha hanya menyetor sejumlah modal (uang) kepada mitranya. Kemudian modal tersebut dikonversikan ke dalam sejumlah saham sebagai bukti kepemilikan usaha. Manajemen untuk menjalankan usahanya diserahkan kepada pihak lain. Usaha seperti ini biasanya dapat dimilki oleh beberapa orang. Ketiga, hanya menyerahkan tenaga namun dikonversikan ke dalam bentuk saham sebagai bukti kepemilikan usaha. 
Ini berarti kepemilikan usaha di bagi dua, yaitu mereka yang memiliki uang dan yang memiliki keahlian. Usaha jenis ini dijalankan dan dimiliki oleh lebih dari satu orang. (Kasmir, 2008: 19).

Telah diketahui bagaimana sebetulnya kegiatan berwirausaha sebagaimana di sebutkan di atas, tapi juga harus diketahui bagaimana sebetulnya persyaratan yang harus disiapkan oleh seseorang yang ingin terjun kedunia wirausaha, adapun syarat-syarat tersebut antara lain: Pertama, Harga Diri. Dengan membuka usaha atau berwirausaha, harga diri seseorang tidak turun, tetapi sebaliknya meningkat. Si pengusaha menjadi kelas tersendiri di masyarakat dan dianggap memiliki wibawa tertentu, seperti disegani dan dihormati. Banyak pengusaha yang sukses dalam menjalankan usahanya menjadi contoh bagi mansyarakat, apalagi mampu memberikan peluang kerja yang sangat dibutuhkan. Kedua, Penghasilan. Dari sisi penghasilan, memiliki usaha sendiri jelas dapat memberikan penghasilan yang jauh lebih baik jika dibandingkan dengan menjadi pegawai. Meningkatnya penghasilan pengusaha tidak mengenal batas waktu, terkadang ada istilah kalau lagi booming, maka keuntungan akan mengalir seperti air yang tak putus-putusnya, apa saja yang dilakukan selalu memperoleh keuntungan. Ketiga, Ide dan Motivasi. Para wirausaha selalu memiliki ide yang begitu banyak untuk menjalankan kegiatan usahanya. Telinga, mulut, dan mata selalu memberikan inspirasi untuk menangkap setiap peluang yang ada. Pengusaha juga memiliki motivasi yang tinggi untuk maju. Terpikir, melihat atau mendengar sesuatu selalu menjadi ide melekat dalam hatii seorang pengusaha. Keempat, Masa Depan. Seorang wirausahawan tidak pernah pensiun dan usaha yang dijalankan dapat diteruskan generasi selanjutnya. Oleh karena itu kita sering mendengar suatu usaha yang bisa dikelola sampai tujuh turunan. Estafet kepemimpinan dalam keluarga yang silih berganti menunjukkan bahwa keberhasilan masa depan wirausaha seperti tak pernah putus.

Beberapa persyaratan sebagaimana dikemukakan di atas, yang harus dipenuhi oleh seorang wirausahawan di dalam menjalankan usahanya tentu tidaklah mudah bagai membalikkan telapak tangan. Sehingga dorongan semangat dan minat yang kuat dari seorang wirausahawan mutlak diperlukan.

Jiwa kewirausahaan mendorong minat seseorang untuk mendirikan dan mengelola usaha secara profesional. Dan hendaknya minat tersebut diikuti dengan perencanaan dan perhitungan yang matang. Misalnya dalam memilih atau menyeleksi bidang usaha yang akan dijalankan sesuai dengan prospek dan kemampuan pengusaha. Pemilihan bidang usaha seharusnya disertai dengan berbagai pertimbangan, seperti minat, modal, kemampuan, dan pengalaman. Untuk itu wirausahawan juga harus mengetahui secara persis berbagai unsur yang harus tertanam di dalam jiwa usahawan tersebut.

Menurut Soesarsno (1996) dalam bukunya Muhammad Ismail Yusanto (2002 :33) wirausaha mencakup beberapa unsur penting yang satu dengan lainnya saling terkait, bersinergi, dan tidak terlepas satu sama lain, yaitu : (1) unsur daya pikir (kognitif), (2) unsur keterampilan (psikomotorik), (3) unsur sikap mental (afektif), dan (4) unsur kewaspadaan atau intuisi.

Selain unsur-unsur penting yang disebutkan di atas, menurut Machfoedz (2004: 2-3), seorang wirausaha juga dapat ditunjukkan dengan profil pribadi sebagai berikut : Pertama. Wirausahawan senantiasa menginginkan prestasi prima; Kedua, Wirausahawan tidak takut menjalani pekerjaan yang disertai resiko dengan memperhitungkan besar kecilnya resiko. Ketiga, Wirausahawan adalah orang yang memiliki kepemimpinan yang tumbuh secara alami dan pada umumnya lebih cepat mengidentifikasi permasalahan yang perlu di atasi. Keempat, Wirausahawan mendapatkan kepuasan dalam lambang-lambang keberhasilan yang diluar dirinya. Mereka senang usaha yang mereka bangun dipuji orang, namun mereka menolak apabila pujian ditujukan kepada diri mereka. Kelima, Wirausahawan secara fisik senantiasa tampak lincah dan berbadan sehat (semangat). Mereka mampu bekerja melebihi jam kerja rata-rata yang dilakukan orang lain ketika merintis usaha. Keenam, 
Wirausahawan adalah orang yang memiliki rasa percaya diri yang sangat tinggi dan tidak meragukan kecakapan dan kemampuannya. Ketujuh, Wirausahawan senantiasa menghindari sifat cengeng dalam membentuk pribadi mandiri dan wirausahawan mencari kepuasan diri, karena mereka termotivasi oleh kebutuhan untuk mewujudkan prestasi diri. Kedelapan, Wirausahawan Mencari Kepuasan diri.

Beberapa unsur mendasar dari sosok wirausahawan serta profil yang harus dimilikinya sebagimana yang disebutkan diatas tentu akan semakin meningkatkan kualitas karakter dari sosok wirausahawan tersebut. Semakin berkualitas karakter seorang wirausahawan makan akan semakin sukses kegiatan usaha yang digelutinya. Hal ini sejalan dengan pendapat Casson (2012: 42), menurutnya, teori menunjukkan bahwa kualitas pribadi wirausahawan adalah sebuah faktor yang penting dalam sukses atau gagal sebuah perusahaan.

Jadi sampai disini semakin sangat jelas bahwa betapa pentingnya kualitas karakter seseorang wirausahawan di dalam ia membangun, mengembangkan serta menikmati kesuksesan dari segenap usaha yang telah ia lakukan. Dan kualitas karakter tersebut menjadi jaminan dari sebuah keberhasilan atau kegagalan dalam dunia usahanya tersebut.

\section{MEMBANGUN KARAKTER KEWIRAUSAHAAN PADA ANAK}

Pembentukan bangunan karakter pada seseorang terlebih bila disematkan pada anak-anak sedini mungkin tentu akan lebih bermanfaat dan berguna bagi pembentukan karakter yang mulia bagi seseorang di dalam mengembangkan dan memajukan diri, lingkungan maupun bangsa dan negara dimanapun orang itu berada. Oleh karena itu, pembangunan karakter yang dilakukan sedini mungkin tentu akan sangat berguna dalam menyematkan berbagai karakter yang mulia pada anak-anak.

Membangun karakter terutama pada seseorang yang masih dalam proses perkembangan tentunya harus dilakukan sedini mungkin. Hal itu dilakukan guna pembentukan pondasi karakter yang benar-benar dapat tertanam atau tersemat dengan utuh pada mereka hingga dewasa kelak.

Menurut Winda Dewi Listyasari dalam Semiawan (2011: 195), pengembangan karakter pada seorang anak sudah dapat dimulai sejak dini mulai dari lingkungan rumah terutama dari kedua orangtuanya, karena orangtua merupakan pendidik pertama dan utama bagi anak-anaknya.

Pendidikan karakter, tentu saja bukan hanya merupakan tanggungjawab sekolah.Pendidikan karakter merupakan tanggungjawab bersama dari mereka semua yang menyentuh nilai dan kehidupan para anak muda, berawal dengan keluarga dan meluas hingga komunitas iman, organisasi pemuda, bisnis, pemerintahan, dan bahkan media. (Lickona, 2013: 4)

Pada inti pendidikan karakter terdapat kemitraan yang kuat antara orangtua dan sekolah.Keluarga adalah aliran kebaikan pertama. Keluarga adalah tempat dimana kita belajar tentang kasih.Keluarga adalah tempat dimana kita belajar tentang komitmen, pengorbanan, dan keyakinan dalam sesuatu yang lebih besar daripada diri kita sendiri. Keluarga meletakkan landasan moral yang diatasnya seluruh institusi sosial lainnya dibangun. (Lickona, 2013: 4).

Membangun karakter berjiwa wirausaha pada anak dengan cara memberikan pendidikan pada mereka baik melakukan penerapan pendidikan di rumah atau dilingkungan keluarga, dilingkungan sosial atau masyarakat maupun pendidikan disekolah harus dengan mengedepankan proses pembangunan karakter kewirausahaan itu sendiri.

Menurut Mas'ud Machfoedz dan Mahmud Machfoedz (2008:13-14), karakter wirausahawan dapat dikemukakan sebagai berikut: Pertama, Wirausahawan memiliki kepercayaan dan pengendalian diri pada saat mereka sedang melaksanakan pekerjaan. Mereka mampu mengatasi permasalahan dengan cepat dan gigih dalam mengejar tujuan. Kedua, Wirausahawan selalu mencari aktivitas. Mereka 
tidak dapat duduk menunggu aktivitas yang akan diberikan orang lain kepada mereka. Diam tanpa aktivitas bukan sifat mereka. Ketiga, Wirausahawan mampu mengendalikan diri. Dalam olah raga mereka pada umumnya lebih menyukai jenis olah raga perorangan daripada permainan tim. Mereka menyukai permainan yang membuat otot dan otak mereka secara langsung berpengaruh pada hasil akhir dan kecepatan permainan. Mereka mempunyai inisiatif, energik, dan tidak mengenal lelah dalam mengejar tujuan. Keempat, Wirausahawan mengelola pekerjaan berdasar tujuan.Mereka mampu memahami situasi rumit yang mungkin mencakup perencanaan, pengambilan keputusan strategis, dan yang mempengaruhi ide bisnis berganda secara simultan. Mereka senantiasa menyadari pentingnya rincian dan secara berkesinambungan meninjau segala kemungkinan demi tercapainya tujuan perusahaan. Kelima, Wirausahawan adalah penganalisis kesempatan. Mereka akan menganalisis dengan cermat setiap kesempatan sebelum dapat meyakini manfaat kesempatan tersebut bagi dirinya. Keenam, Wirausahawan adalah pemikir yang kratif. Mereka tidak mengikuti cara berpikir yang telah menjadi kebiasaan dan dilakukan oleh orang pada umumnya. Hal yang telah menjadi kebiasaan tidak melahirkan solusi baru yang merupakan tuntutan usaha kecil pada masa dewasa ini. Ketujuh, Wirausahawan adalah orang yang mampu memecahkan persoalan. Mereka mempunyai pemahaman yang jelas tentang sesuatu yang ingin mereka capai dan dapat dengan cepat mengatasi permasalahan dalam cara yang mereka tempuh. Kedelapan, Wirausahawan adalah pemikir yang objektif. Ketika seseorang wirausahawan menemukan solusi atas suatu permasalahan, dia akan bertukar pikiran dengan orang-orang yang berkompeten untuk menghindari pengambilan keputusan sendiri. Mereka akan menerima modifikasi solusi yang logis dan akan mengubah solusi mereka sesuai dengan alternatif yang lebih baik. Wirausahawan tidak membiarkan sifat mementingkan diri mengesampingkan obyektifitas.

Dari delapan karakter wirausahawan sebagaimana dikemukakan di atas, tentunya dapat dielaborasi ke dalam upaya penanaman karakter tersebut dalam bingkai pendidikan, baik di rumah atau lingkungan keluarga, di masyarakat, maupun di sekolah. Artinya baik orangtua, tokoh masyarakat, mapun guru di sekolah berkewajiban untuk membangun karakter kewirausahaan pada anak, dengan cara : Pertama, Menumbuhkembangkan kepercayaan diri anak, artinya tidak cepat rendah diri sehingga menimbulkan rasa tidak percaya diri. Kedua, Menumbuhkembangkan semangat kerja keras atau keinginan selalu beraktivitas, tidak bermalas-malasan. Ketiga, Menumbuhkembangkan sikap mawas diri sehingga mereka mampu mengendalikan diri, tidak mudah terhanyut dalam suasana yang diciptakan oleh orang atau pihak lain. Keempat, Menumbuhkembangkan sikap teguh keyakinan atau Istiqomah sehingga kelak mereka mampu mengelola suatu usaha atau pekerjaan berdasarkan tujuan yang telah digariskan. Kelima, Menumbuhkembangkan kecermatan atau ketelitian sehingga mampu dengan cepat membaca peluang dan kesemptan yang ada disekitar mereka. Keenam, Menumbuhkembangkan pola pikir kreatif.Hal ini sangat dibutuhkan oleh anak yang ingin dibentuk sebagai wirausahawan karena karakter ini sebagai salah satu karakter kunci dalam ranah kewirausahaan. Ketujuh, Menumbuhkembangkan kemampuan problem solving atau memecahkan persoalan atau masalah. Sehingga jika mereka tertimpa persoalan atau masalah mereka tidak lari dari masalah tersebut yang dapat berakibat mereka dinilai tidak bertanggung jawab karena menghindari segala persoalan yang ada. Kedelapan, Menumbuhkembangkan sikap objektif dalam memandang atau menilai sesuatu, tidak berat sebelah atau tebang pilih sesuai dengan selera pribadi. Obyektifitas ini sangat penting karena hal tersebut dapat menyelamatkan seseorang dari segala kesalahan tindak yang menyebabkan kekacauan atau mungkin juga kehancuran usaha.

Penumbuhkembangan delapan karakter kewirausahaan di atas, harus pula dilakukan dengan cara-cara yang tepat dan akurat sehingga upaya membangun karakter kewirausahaan pada anak tidak 
sia-sia. Artinya upaya penyematan nilai-nilai atau karakter sebagaimana di sebutkan di atas benar-benar tertancap dan "mendarah daging" pada si anak.

Melakukan upaya pendidikan secara tepat dan akurat terlebih dalam menanamkan nilai-nilai karater pada anak haruslah dilakukan secara berulang-ulang.Menurut Prof. Herman Ebbinghause seorang ahli Psikologi dan Pendidikan menyebutkan, kalau mau memahami isi buku 2\% saja harus membacanya 20 kali. Karena itulah mengapa banyak yang berpendapat bahwa merobah mental bangsa memerlukan waktu puluhan tahun. Namun demikian, masalah diperlukannya teknik berulang-ulang ini, dapat memanfaatkan penggunaan komputer. Contohnya dengan membuat disket maupun video kaset yang berisi program atau sinetron pendidikan yang bisa diputar berulang-ulang. (Sumahamijaya dkk : 2017).

Selain hal tersebut di atas, menurut Sri Endang Susetiawati dalam Asmani (2011: 72-73), dalam konteks sistem pendidikan di sekolah, sekurang-kurangnya pendidikan karakter harus memperhatikan beberapa hal, Pertama, Pendidikan karakter harus menempatkan kembali peran guru sebagai faktor yang sangat penting dalam pengembangan kepribadian peserta didik. Guru harus dikembalikan pada hakikatnya sebagai pendidik, bukan sebagai pengajar semata yang harus mentrasnfer pengetahuan di ruang kelas. Sebagai pendidik guru harus lebih berperan dalam mendidik dan mengembangkan kepribadian siswa melalui interaksi yang intensif, baik selama di ruang kelas maupun di luar kelas. Kedua, Pengembalian peran guru sebagai pendidik perlu diikuti oleh sebuah sistem pembelajaran yang sungguh-sungguh menempatkan sosok guru sebagai orang yang paling tahu tentang kondisi dan perkembangan anak didiknya, khususnya yang berkaitan dengan masalah kepribadian atau karakter siswa tersebut. hal ini berarti mensyaratkan salah satu aspek penting dalam proses pembelajaran, yaitu sistem penilaian (evaluasi) perlu dikembalikan sebagai hak mutlak guru yang menentukan. Ketiga, Sebagai bagian dari sistem pendidikan karakter, perlu digalakkan kembali sebuah sistem evaluasi yang lebih menitik beratkan pada penilaian aspek afektif, yang disana karakter tersebut berada. Sistem penilaian perlu mengedepankan sesuatu yang lebih menjangkau karakteristik seorang anak didik, caranya adalah mengembangkan sistem evaluasi yang berbentuk essay. Bentuk penilaian essay dianggap jauh lebih mampu menjangkau penilaian aspek karakter seorang siswa. Serta sebagai bagian dari proses pembentukan karakter yang positif, yang meliputi kejujuran, kemandirian, kemampuan berkomunikasi, struktur logika, dan lain sebagainya.

Jadi akurasi atau ketepatan dalam membangun karekter kewirausahaan yang merupakan karakter mulia pada anak perlu dilakukan secara berulang-ulang dan berkesinambungan, selain itu juga dibutuhkan peranserta orangtua di rumah, tokoh masyarakat di lingkungan sosial si anak berada, dan juga guru di sekolah untuk dapat memposisikan diri sebagai pendidik yang cenderung memberikan bimbingan dan arahan yang positif, bukan sekedar melakukan pemaksaan kehendak kepada anak khususnya dalam menyematkan karakter kewirausahaan pada mereka. Dengan mengedepankan cara pembelajaran yang penuh dengan ketulusan dan kelembutan tentunya ranah afektif si anak akan lebih tersentuh dan selanjutnya membelas kuat dan "mendarah daging" dalam karakter mereka. Di dalam perspektif agama khususnya Islam, hal ini termuat di dalam Al-qur'an pada Surat 16, Ayat 125, yang artinya : "Serulah (manusia) kepada jalan Tuhan-mu dengan bikmabdan pengajaran yang baik dan berdebatlah dengan mereka dengan cara yang baik. Sesunggubnya Tubanmu dialah yang lebih mengetahui tentang siapa yang tersesat dari jalan-Nya dan Dialah yang lebih mengetabui siapa yang sesat dari jalannya dan Dialah yang lebih mengetahui siapa yang mendapat petunjuk". 


\section{PENUTUP}

Dari uraian di atas, tentang upaya membangun karakter mulia pada anak dalam perspektif kewirausahaan, dapat disimpulkan beberapa hal, antara lain :

1. Karakter merupakan suatu hal yang sangat penting bagi setiap individu terutama anak-anak, karenanya menuntut orangtua, guru maupun lingkungan sekitar untuk dapat menyematkan suatu karakter yang mulia pada anak. Dan karakter tersebut haruslah dapat menjawab berbagai problema kekinian pada lingkungan masyarakat maupun Negara Republik Indonesia ini.

2. Problema bangsa saat ini menuntut kemampuan segenap warga bangsa untuk dapat memulihkan kondisi ekonomi, sehingga penanaman karakter berjiwa wirausaha menjadi suatu karakter yang patut di kembangkan khususnya kepada anak-anak generasi bangsa guna meningkatkan kemampuan bangsa di sektor ekonomi ke depan.

3. Dalam membangun karakter berjiwa wirausaha pada anak dengan cara memberikan pendidikan pada mereka baik melakukan penerapan pendidikan di rumah atau dilingkungan keluarga, di lingkungan sosial atau masyarakat maupun pendidikan disekolah harus dengan mengedepankan proses pembangunan karakter kewirausahaan itu sendiri.

4. Penumbuhkembangan karakter berjiwa wirausaha atau kewirausahaan dapat dilakukan dengan cara: Pertama, Menumbuhkembangkan kepercayaan diri anak. Kedua, Menumbuhkembangkan semangat kerja keras atau keinginan selalu beraktivitas. Ketiga, Menumbuhkembangkan sikap mawas diri sehingga mereka mampu mengendalikan diri.Keempat, Menumbuhkembangkan sikap teguh keyakinan atau Istiqomah. Kelima, Menumbuhkembangkan kecermatan atau ketelitian. Keenam, Menumbuhkembangkan pola pikir kreatif. Ketujuh, Menumbuhkembangkan kemampuan problem solving atau memecahkan persoalan atau masalah. Kedelapan, Menumbuhkembangkan sikap objektif dalam memandang atau menilai sesuatu.

5. Membangun karakter kewirausahaan harus dilakukan dengan cara-cara yang tepat dan akurat sehingga upaya membangun karakter kewirausahaan pada anak tidak sia-sia. Dan upaya itu dilakukan dengancara melakukan penyampaian secara berulang-ulang dan berkesinambungan, selain itu juga dibutuhkan peranserta orangtua di rumah, tokoh masyarakat di lingkungan sosial si anak berada, dan juga guru di sekolah untuk dapat memposisikan diri sebagai pendidik yang cenderung memberikan bimbingan dan arahan yang positif, bukan sekedar melakukan pemaksaan kehendak kepada anak khususnya dalam menyematkan karakter kewirausahaan pada mereka. Dengan mengedepankan cara pembelajaran yang penuh dengan ketulusan dan kelembutan tentunya ranah afektif si anak akan lebih tersentuh dan selanjutnya membelas kuat dan "mendarah daging" dalam karakter mereka.

\section{REFERENSI}

Alma, Buchari. 2011. Kewirausahaan untuk Mabasiswa dan Umum, Alfabeta, Bandung.

Asmani, Jamal Ma'mur. 2011. Buku Panduan Internalisasi Pendidikan Karakter di Sekolah, Diva Press, Yogyakarta.

Benedicta Prihatin Dwi Riynti. 2003. Kewirausahaan dari Sudut Pandang Psikologi Kepribadian, Penerbit PT Gamedia Widiasarana Indonesia, Jakarta.

Boone \& Kurtz. 2002. Pengantar Bisnis Jilid 1, Penerbit Erlangga Jakarta. 
Casson, Mark. 2012. Entrepreneurship, Teori, Jejaring, Sejarah, Rajawali Press, Jakarta.

Dinsi, Valentino. 2005. Jangan Mau Seumur hidup Jadi Orang Gajian, Let’s Go Indonesia, Jakarta.

Direktur Produktivitas dan Kewirausahaan. 2011. Penerapan 5 S Dalam Keluarga, Kementerian Tenaga Kerja dan Transmigrasi RI, Jakarta.

Hadari Nawawi dkk. 1994. Manusia Berkualitas, Gadjah Mada University Press, Yogyakarta.

Hendro. 2011. Dasar-dasar Kewirausahaan, Erlangga, Jakarta.

Kasmir. 2006. Kewirausahaan, PT. Raja Grafindo Persada, Jakarta.

Lickona, Thomas. 2013. Character Matters Persoalan Karakter, Bumi Aksara, Jakarta.

Machfoedz, Mas'ud dan Machfoedz, Mahmud. 2004. Kewirausahaan Suatu Pendekatan Kontemporer, UPP AMP YKPN, Yogyakarta.

Machfoedz, Mas'ud dan Machfoedz, Mahmud. 2008. Kewirausahaan Metode, Manajemen, dan Implementasi, BPFE UGM, Yogyakarta.

Rusdiana, H.A, 2014, Kemirausahaan Teori dan Praktek, CV. Pustaka Setia, Bandung.

Sumahamijaya, Suparman, dkk. 2003. Pendidikan Karakter Mandiri dan Kewirausahaan, Angkasa, Bandung.

Semiawan, Conny dkk. Editor. 2011. Alih Kepakaran, Gocara Press, Bogor.

Lajnah Pentashihan Mushaf AlQur'an. 2013. Al-Qur'an Dan Terjemahannya, PT. Hati Emas, Jakarta. 